\title{
Perceptions and Attitudes towards Evidence Based Practice among Nurses and Nursing Students in Nepal
}

Karki $\mathrm{S},{ }^{1}$ Acharya $\mathrm{R},{ }^{1}$ Budhwani $\mathrm{H},{ }^{2}$ Shrestha $\mathrm{P},{ }^{1}$ Chalise $\mathrm{P},{ }^{1}$ Shrestha $\mathrm{U},{ }^{1}$ Gautam $\mathrm{K},{ }^{1}$ Wilson $\mathrm{L}^{2}$

${ }^{1}$ Department of Nursing

Kathmandu University School of Medical Sciences Dhulikhel, Kavre, Nepal.

${ }^{2}$ University of Alabama at Birmingham, USA.

Corresponding Author

Sita Karki

Department of Nursing

Kathmandu University School of Medical Sciences

Dhulikhel, Kavre, Nepal.

E-mail: sitakarki_2000@yahoo.com

\section{Citation}

Karki S, Acharya R, Budhwani H, Shrestha P, Chalise $P$, Shrestha $U$, et al. Perceptions and Attitudes towards Evidence Based Practice among Nurses and Nursing Students in Nepal. Kathmandu Univ Med J 2015;52(4):308-15.

\section{ABSTRACT}

\section{Background}

As the evidence based practice (EBP) movement expands, there is a need for health leaders and educators in each country to assess the extent to which health professional students and practitioners are prepared to locate, evaluate, and apply evidence to guide their practice.

\section{Objective}

The study objective was to explore nurses' and nursing students' perceptions and attitudes towards EBP.

\section{Method}

This was a descriptive cross-sectional survey administered to all 273 nurses and nursing students from Nepal who attended an EBP conference. The survey instrument that was used by Majid in Singapore was adapted for use in this study with permission from the author.

\section{Result}

In total, 121 nurses participated in the study. The majority (93\%) of respondents reported that they had no previous training in EBP. The respondents' perceptions of their EBP knowledge and skills were variable, but most of them demonstrated positive attitudes toward EBP. Respondents identified a number of barriers that limit the implementation of EBP in Nepal. The greatest barriers were lack of time and resources, difficulty understanding research articles and translating the findings to practice, and limited autonomy to change practice based on evidence.

\section{Conclusion}

Although respondents had positive attitudes towards EBP, their knowledge and skills were limited and barriers to implementation existed. Nursing faculty can use the findings to guide implementation of EBP into curricula, and nursing administrators and clinicians can use the findings to guide practice to promote EBP.

\section{KEY WORDS}

Evidence-based nursing, evidence-based practice, nursing research 


\section{INTRODUCTION}

The evidence based practice (EBP) movement has expanded across the globe, and led to demands for evidence-based policy making and evidence-based public health. ${ }^{1-4}$ Despite the emphasis on EBP and the extensive research that documents its value, many nurses do not use evidence to guide their practice., ${ }^{5,6}$ As the EBP movement expands, there is a need for health professional leaders and educators in each country to assess the extent to which health professional students and practitioners are prepared to locate, evaluate, and apply evidence to guide their practice.

\section{METHODS}

As a first step in addressing the need to enhance EBP among nurses in Nepal, the Kathmandu University School of Medical Sciences (KUSMS) sponsored the first international nursing conference on EBP in Dhulikhel, Nepal in November 2014. This was a descriptive cross-sectional survey administered to all 273 nurses and nursing students from Nepal who attended the EBP conference. The purpose of this paper is to present results of a survey of attitudes and perceptions towards EBP among a sample of nurses and nursing students who attended this conference. The Institutional Review Board of the University of Alabama at Birmingham (UAB) approved the study, and the KUSMS Institutional Review Committee authorized the conduct of the study, after determining that the project was exempted from the requirement for a formal review.

The survey instrument that was used by Majid in Singapore was adapted for use in this study, with permission from the author. The instrument was developed based on a review of existing surveys, adding items that addressed nurses' literature searching skills. The authors reported content validity, and internal consistency reliability (Cronbach's Alpha) ranging from 0.68 to 0.95 on the different subscales of the instrument. The adapted instrument used in this study consisted of: (i) four questions about demographic information and previous training in EBP; (ii) five (yes/no) questions assessing knowledge of the components of EBP; (iii) five Likert-scale questions assessing attitudes towards EBP; (iv) nine Likert-scale questions assessing perceived level of skill in performing the different components of $\mathrm{EBP}$; (v) ten Likert-scale questions assessing perceived barriers to EBP; (vi) seven Likert-scale questions assessing perceptions about factors that would promote their use of EBP; (vii) eight Likert-scale questions about specific EBP training needs; and (viii) eighteen Likert-scale questions asking about the use of different types of information for nursing care and making clinical decision. A copy of the revised instrument is available upon request. Some of the questions on the original survey that focused on specific literature search strategies (such as knowledge of Boolean terminology) were deleted for the revision of the instrument that was used in the present study. The Nepali members of the research team reviewed the revised instrument and made several small modifications for clarity. Cronbach's alpha reliabilities are reported for the various scales in the presentation of the findings below.

All nurses and students who attended the two day EBP conference received a copy of the survey and a cover letter inviting them to complete the survey during the course of the conference if they met the following inclusion criteria: (i) a registered nurse in Nepal; (ii) a nursing student in Nepal; (iii) proficient in reading and writing in English. Participants were asked to return completed surveys to designated boxes that were located near the conference registration desk. Conference participants were assured that their participation was voluntary, and their responses were anonymous. At the end of the conference the surveys were collected, responses were transferred to an excel database and subsequently analyzed using the Statistical Package for the Social Sciences (SPSS), version 22.

\section{RESULTS}

\section{Sample Characteristics}

A total of $121 / 273$ (44\%) conference participants responded to the survey, including 50 nursing students. More detail information about the demographic information of the participants are shown in table 1.

Table 1. Demographic information

\begin{tabular}{|lll|}
\hline Demographic information & N & $\%$ \\
\hline Experience of respondents & & \\
\hline 1-5 years & 52 & 43 \\
\hline 6-10 years & 30 & 24.8 \\
\hline More than 10 years & 16 & 13.2 \\
\hline Students having no experience & 23 & 19.0 \\
\hline Education level (Missing data for 1 participant) & & \\
\hline Students & 50 & 41.3 \\
\hline Certificate/ Diploma in Nursing & 2 & 1.7 \\
\hline Post Basic/ Advanced Diploma in Nursing & 4 & 3.3 \\
\hline Bachelor's Degree in Nursing & 44 & 36.7 \\
\hline Master Degree in Nursing & 18 & 15 \\
\hline Others & 2 & 1.7 \\
\hline Working Place (Missing data for 12 participants) & & \\
\hline Hospital & 48 & 39.7 \\
\hline School of Nursing & 35 & 28.9 \\
\hline Other or Student & 26 & 21.5 \\
\hline
\end{tabular}

\section{Previous training in EBP}

Most of the respondents ( $n=113$, or $93 \%$ ) indicated that they had no previous training about EBP. Only three respondents indicated that they had received EBP training, and five did not answer this question. The types of training 
received by these three respondents included a 3-day EBP course, training in Essential Burn Care, and training about qualitative research.

\section{Knowledge about EBP}

Knowledge about EBP was measured by asking respondents to indicate whether they believed that they were adopting EBP when they implemented nursing care based on five components of EBP. 'Yes' responses were interpreted as indicating accurate EBP knowledge. Thus, possible knowledge scores could range from 0-5. Table 2 presents the responses to each question.

\section{Table 2. Responses to questions assessing EBP knowledge}

\begin{tabular}{|ll|}
$\begin{array}{l}\text { Question - 'I believe I am adopting EBP when I } \\
\text { implement nursing care based on..." }\end{array}$ & $\begin{array}{l}\text { Number (\%) } \\
\text { Responding Yes }\end{array}$ \\
\hline Patients' subjective and objective data & $71(58.7)$ \\
\hline Information from text books & $67(55.4)$ \\
\hline Previous experiences of health care professionals & $59(48.8)$ \\
\hline Research findings & $78(64.5)$ \\
\hline Patients' values and preferences & $57(47.1)$
\end{tabular}

To assess Nepalese nurses' holistic understanding of EBP, a composite measure was developed which summarized affirmative responses to this series of questions ( $1=Y e s$; $0=\mathrm{No})$. Responses ranged from $0-5$, with a mean of 2.74. Five percent of respondents answered 'no' to all questions as compared to $21 \%$ who scored the maximum of five points. About $46 \%$ of respondents scored between a $0-2$, while about $53 \%$ scored between a $3-5$, indicating variability in nurses' knowledge about EBP.

\section{Attitudes towards EBP}

Attitudes towards EBP were assessed by respondents' indicating their level of agreement to five statements on a 5-point Likert scale (1=Strongly Agree; 5=Strongly Disagree) to five questions. Lower scores (reflecting higher levels of agreement to the statements) reflected more negative attitudes, and higher scores reflected more positive attitudes. Responses are summarized in Table 3. The Cronbach's Alpha reliability for this scale was 0.63 . Findings presented in Table 3 indicate that $53 \%$ of the respondents indicated that they could not keep up to date with new evidence due to heavy workloads. Positive attitudes were reflected by the overall mean score of 3.6, and by the high number of respondents who disagreed with the statements that they preferred using traditional methods over new patient care approaches or that they do not like people questioning their clinical practices based on established methods ( $86 \%$ and $71 \%$, respectively).

\section{Perceived skills in EBP}

Perceived skills in EBP were assessed by asking participants to rate on a 6-point Likert scale their perceived skill level in nine aspects of EBP (see Table 4), with one representing poor and six representing excellent. The Cronbach's Alpha
Table 3. Measure of Attitudes towards EBP

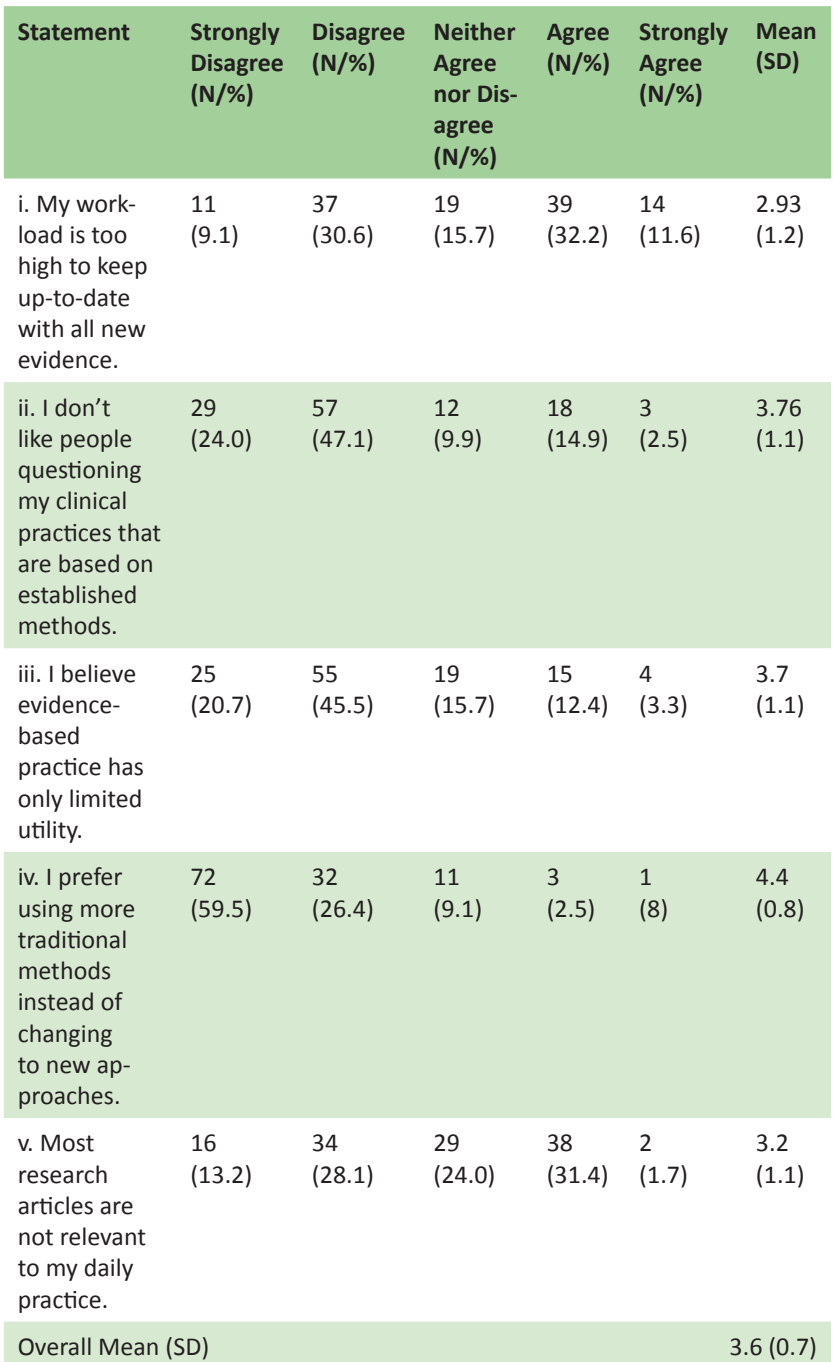

reliability for this scale was 0.865 . Table 4 indicates the percentage of responses in each category, and the mean rating for each category. Mean scores on these items ranged from 3.76-4.36 and the overall mean was 4.1, suggesting that the respondents perceived that they had moderate skills in EBP. The lowest scores were for items related to assess research articles using checklists, and apply interventions based on best applicable evidence. These findings can be used to identify priorities for EBP educational programs for nurses in Nepal.

\section{Perceived barriers to EBP}

Perceived barriers to EBP were assessed by asking participants rate their level of agreement on a list of nine potential barriers to EBP, using a 5-point Likert scale (1=Strongly Agree, 5=Strongly Disagree). Lower mean scores indicate greater perception of the item as a barrier to EBP. The Chronbach's Alpha reliability for this scale was 0.79. Table 5 summaries the percentage responding to each category, and the mean score for each barrier. A total of 19 participants also made comments identifying other barriers, and themes reflected in those comments are also summarized in the last row of Table 5 . 


\section{Table 4. Perceived EBP Skills}

\begin{tabular}{|c|c|c|c|c|c|c|c|}
\hline \multirow[t]{3}{*}{ I am able to: } & \multicolumn{6}{|c|}{ Percentage Responding } & \multirow{3}{*}{$\begin{array}{l}\text { Mean } \\
\text { (SD) }\end{array}$} \\
\hline & \multicolumn{3}{|c|}{ Poor } & & \multicolumn{2}{|c|}{ Excellent } & \\
\hline & 1 & 2 & 3 & 4 & 5 & 6 & \\
\hline $\begin{array}{l}\text { i. identify clinical issues/ } \\
\text { problems. }\end{array}$ & 0.9 & 0 & 17.9 & 29.1 & 30.8 & 11.1 & $\begin{array}{l}4.36 \\
(1.0)\end{array}$ \\
\hline $\begin{array}{l}\text { ii. translate a clinical } \\
\text { issue/problem into a } \\
\text { well-formulated clinical } \\
\text { question. }\end{array}$ & - & 5 & 15.7 & 48.8 & 24.0 & 5.0 & $\begin{array}{l}4.08 \\
(0.9)\end{array}$ \\
\hline $\begin{array}{l}\text { iii. distinguish be- } \\
\text { tween different types } \\
\text { of questions (e.g. } \\
\text { intervention,prognosis, } \\
\text { harm, and cost-effective- } \\
\text { ness). }\end{array}$ & - & 0.8 & 3.3 & 6.7 & 19.2 & 25.0 & $\begin{array}{l}4.25 \\
(1.0)\end{array}$ \\
\hline $\begin{array}{l}\text { iv. conduct online search- } \\
\text { es (using databases and } \\
\text { web search engines). }\end{array}$ & 3.3 & 6.7 & 19.2 & 25.0 & 33.3 & 11.7 & $\begin{array}{l}4.14 \\
(1.2)\end{array}$ \\
\hline
\end{tabular}

$\begin{array}{llllllll}\text { v. relate research finding } & 1.7 & 4.3 & 14.5 & 34.2 & 28.2 & 12.0 & 4.25\end{array}$ to my clinical practice and point out similarities and differences (when reading a research article)

$\begin{array}{llllllll}\text { vi. use check list to assess } & 6.7 & 9.2 & 26.9 & 26.9 & 19.3 & 9.2 & 3.72\end{array}$

research articles.

$\begin{array}{llllllll}\text { vii. read a research report } & 4.2 & 8.4 & 19.3 & 30.3 & 23.5 & 12.6 & 4.00\end{array}$ and have a general notion about its strength and weaknesses.

$\begin{array}{llllllll}\text { viii. apply an intervention } & 5.1 & 5.9 & 23.7 & 31.4 & 22.9 & 7.6 & 3.87\end{array}$ based on the most applicable evidence.

$\begin{array}{llllllll}\text { ix. evaluate the applica- } & 1.7 & 5.9 & 19.3 & 37.8 & 26.9 & 6.7 & 4.04\end{array}$ tion of intervention and identify areas of improvement.

Overall Mean (SD) $4.1(0.8)$

\section{Table 5. Perceived Barriers to EBP}

\begin{tabular}{|c|c|c|c|c|c|c|}
\hline Barriers & $\begin{array}{l}\text { Strongly } \\
\text { Disagree }\end{array}$ & Disagree & $\begin{array}{l}\text { Neither Agree } \\
\text { nor Disagree }\end{array}$ & Agree & $\begin{array}{l}\text { Strongly } \\
\text { Agree }\end{array}$ & $\begin{array}{l}\text { Mean } \\
\text { (SD) }\end{array}$ \\
\hline i. Inadequate understanding of research terms used in research articles. & 5.0 & 38.7 & 13.4 & 37.8 & 5.0 & $3.0(1.1)$ \\
\hline ii. Inability to understand statistical terms used in research articles. & 5.1 & 33.1 & 11.9 & 44.1 & 5.9 & $2.87(1.1)$ \\
\hline iii. Difficulty in judging the quality of research papers and reports. & 3.4 & 22.4 & 13.8 & 48.3 & 12.1 & $2.6(1.1)$ \\
\hline iv. Inability to properly interpret the results of research studies. & 5.9 & 35.6 & 12.7 & 43.2 & 2.5 & $3.0(1.1)$ \\
\hline v. Difficulty in determining the applicability of research findings. & 2.5 & 29.4 & 20.2 & 44.5 & 3.4 & $2.8(0.9)$ \\
\hline $\begin{array}{l}\text { vi. Inability to implement recommendations of research studies into } \\
\text { clinical practice. }\end{array}$ & 6.8 & 23.7 & 13.6 & 50.0 & 5.9 & $2.8(1.1)$ \\
\hline $\begin{array}{l}\text { vii. Difficulty in finding time at work place to search for and read research } \\
\text { articles and reports. }\end{array}$ & 5.9 & 16.8 & 19.3 & 40.3 & 17.6 & $2.5(1.1)$ \\
\hline $\begin{array}{l}\text { viii. Insufficient time at work place to implement changes in their current } \\
\text { practice. }\end{array}$ & 7.6 & 17.6 & 18.5 & 47.1 & 9.2 & $2.7(1.1)$ \\
\hline ix. Insufficient resources (e.g. equipment, materials) to implement EBP. & 2.5 & 8.4 & 16.8 & 52.9 & 19.3 & $2.2(0.9)$ \\
\hline Overall Barriers Mean (SD) & & & & & & $2.7(0.7)$ \\
\hline x. Other barriers (19 comments received and are summarized in this row) & \multicolumn{6}{|c|}{$\begin{array}{l}\text { Resistance to change by organization or colleagues (5), lack of valuing of } \\
\text { EBP, environment does not encourage EBP, hospital does not provide access } \\
\text { to journals or internet (2); inadequate guidance and support (2), insuffi- } \\
\text { cient resources ( } 2 \text { ); limited time; lack of cooperation; lack of support from } \\
\text { administrators (3); mental stress; patients' values and norms; clinical issues; } \\
\text { limited availability of relevant research; workload; }\end{array}$} \\
\hline
\end{tabular}

The overall mean for this scale was 2.7 , suggesting that the respondents perceived significant barriers to EBP. More than $72.2 \%$ of the nurses either "agreed" or "strongly agreed" with the statement that the major barrier to their adoption of EBP was insufficient resources (equipment, material). The next two most commonly identified barriers were difficulty in judging the quality of research paper and report and difficulty in finding time at work place to search research articles. These findings have implications for identifying strategies that could be used to promote EBP among nurses in Nepal.

\section{Perceived motivators to facilitate EBP}

Participants were also asked to rate the importance of a set of potential motivating factors that they thought would facilitate implementation of EBP, rating each factor on a 5-point Liker scale (1=Least Important, 5=Extremely Important). The Cronbach's Alpha reliabliiy for this subscale was 0.69 . The overall mean for this scale was 4.3 , suggesting that respondents perceived most motivators as important. Table 6 summarizes the percentage rating each score and the overall mean for each factor.

In addition to rating the various motivators, the survey included an open-ended question asking participants to describe measures that would be desirable to make EBP successful in their workplaces. A total of 52 respondents made comments, and these comments were analyzed using the MAXQDA2 (C) Qualitative Data Analysis software. The major categories that emerged from a qualitative content analysis of these comments are listed in Table 7. Sample comments that were coded in each theme are presented in the middle column in italics. 


\section{Table 6. Perceived EBP Motivators}

\begin{tabular}{|c|c|c|c|c|c|c|}
\hline Motivators & $\begin{array}{l}\text { Least } \\
\text { Important }\end{array}$ & $\begin{array}{l}\text { Somewhat } \\
\text { Important }\end{array}$ & Important & $\begin{array}{l}\text { More } \\
\text { Important }\end{array}$ & $\begin{array}{l}\text { Extremely } \\
\text { Important }\end{array}$ & $\begin{array}{l}\text { Mean } \\
\text { (SD) }\end{array}$ \\
\hline i. Nursing colleagues who embrace EBP & 6.7 & 2.9 & 10.6 & 44.2 & 35.6 & $3.9(1.1)$ \\
\hline ii. Nursing management who embrace EBP & 4.2 & 0.8 & 7.6 & 36.1 & 51.3 & $4.3(0.9)$ \\
\hline iii. Given adequate training in EBP & 0 & 0 & 6.7 & 27.7 & 65.5 & $4.6(0.6)$ \\
\hline iv. Given protected time to conduct EBP & 0 & 1.7 & 9.5 & 35.3 & 53.4 & $4.4(0.7)$ \\
\hline v. Access to a system for comprehensive literature searching & 0 & 0.8 & 14.2 & 32.5 & 52.5 & $4.4(0.7)$ \\
\hline vi. Mentoring by nurses who have adequate EBP experience & 0.8 & 2.5 & 6.7 & 34.5 & 55.5 & $4.4(0.8)$ \\
\hline \multicolumn{6}{|c|}{ Overall Mean (sd) } & $4.3(0.5)$ \\
\hline Other ( $n=9$ comments) & \multicolumn{6}{|c|}{$\begin{array}{l}\text { Availability of suitable environment; availability of equipment (3); Ad- } \\
\text { equate resources; Encouragement to do more research; Policies to make } \\
\text { EBP compulsive; Guidance }\end{array}$} \\
\hline
\end{tabular}

Table 7. Themes Reflecting Recommended Measures to Make EBP Successful

\begin{tabular}{|c|c|c|}
\hline Code & Example of Comment Coded in the Category & $\begin{array}{l}\text { Number of } \\
\text { Comments }\end{array}$ \\
\hline Training in or Knowledge About EBP & $\begin{array}{l}\text { The most important thing is the training that should be provided to all nursing personnel in } \\
\text { order to firstly be familiar with the basic terms about EBP }\end{array}$ & 36 \\
\hline Resources for EBP & Sufficient journal articles, proper access to health data base (PubMed, Research gate) & 16 \\
\hline Adequate Time & Sufficient time for literature review & 12 \\
\hline Opportunities for Research & Implementation of research conducted in many settings (workplaces) & 11 \\
\hline Encouragement and Motivation & $\begin{array}{l}\text { EBP should be focused from management level i.e nursing matron, supervisor, staffs, } \\
\text { colleagues, awareness, importance and EBP should be enhanced, nurses should have the } \\
\text { decision making authority }\end{array}$ & 11 \\
\hline Supportive Environment & Supportive working environment and self-motivation & 6 \\
\hline Monitoring and Evaluation & Timely evaluation of EBP should be done so that improvements can be done & 5 \\
\hline Journal Club, Meetings, or EBP Rounds & Journal club; Regular EBP rounds & 5 \\
\hline Mentoring & $\begin{array}{l}\text { Mentoring by nurses who have adequate training on EBP practice and adequate manage- } \\
\text { ment to initiate and implement EBP }\end{array}$ & 4 \\
\hline Adequate Staffing & $\begin{array}{l}\text { Assistance from administration through adequate staffing pattern and an appropriate } \\
\text { nurse patient ratio }\end{array}$ & 4 \\
\hline Implementing EBP & Synthesizing evidence and implementing (in) practice & 3 \\
\hline Clear Presentation of Research & Research presentation findings must be simple to understand & 2 \\
\hline Collaboration and Teamwork & Collaboration from all health personnel & 2 \\
\hline Policies & Policies should be made and implemented regarding practices based on evidence & 1 \\
\hline
\end{tabular}

\section{Perceived training needs}

Perceived training needs were assessed by asking participants to rate the level of importance of various types of training that they needed using a 5-point Likert scale (1=least important, 5=extremely important). The Cronbach's Alpha reliability for this subscale was- 0.80 . The overall mean was 4.5 , suggesting that respondents perceived most of the training options identified as important. Responses are summarized in Table 8.

\section{Use of information resources in patient care}

The final question on the survey asked participants to rate the extent to which they used a variety of types of information in providing nursing care, using a 5-point Likert scale (1=never, $2=$ rarely, 3=sometimes, $4=$ often, and $5=a l w a y s)$. The Cronbach's Alpha reliability for this subscale was 0.82 . The overall mean was 3.5 , suggesting that many of these information sources were being used in providing care. Responses are summarized in Table 9.

Textbooks and searching Google were the only information sources that received mean scores above 4.0. The low use of electronic different (digital medical and nursing library, health database, HINARI, eNomed, Scribd) could be due to limited literature searching skills of nurses, or perhaps limited access to these resources in some settings. These findings provide additional guidance for identification of strategies to promote EBP among nurses in Nepal. 


\section{Table 8. Perceived EBP Training Needs}

\begin{tabular}{|c|c|c|c|c|c|c|}
\hline \multirow[t]{2}{*}{ Training Areas } & \multicolumn{2}{|c|}{$\begin{array}{l}\text { Least } \\
\text { Impor- } \\
\text { tant(\%) }\end{array}$} & \multicolumn{3}{|c|}{$\begin{array}{c}\text { Extremely } \\
\text { Important (\%) }\end{array}$} & \multirow[t]{2}{*}{$\begin{array}{l}\text { Mean } \\
\text { (SD) }\end{array}$} \\
\hline & 1 & 2 & 3 & 4 & 5 & \\
\hline $\begin{array}{l}\text { i. Understanding } \\
\text { what is EBP }\end{array}$ & 1.0 & 1.0 & 10.0 & 18.0 & 70.0 & $4.6(0.8)$ \\
\hline $\begin{array}{l}\text { ii. Identifying clinical } \\
\text { issues for implement- } \\
\text { ing EBP }\end{array}$ & 1.7 & 0 & 5.9 & 23.5 & 68.9 & $4.6(0.8)$ \\
\hline $\begin{array}{l}\text { iii. Conducting litera- } \\
\text { ture searches }\end{array}$ & - & 2.5 & 9.2 & 32.5 & 55.8 & $4.4(0.8)$ \\
\hline $\begin{array}{l}\text { iv. Conducting critical } \\
\text { appraisal of articles }\end{array}$ & - & 2.5 & 11.8 & 37.0 & 48.7 & $4.3(0.8)$ \\
\hline $\begin{array}{l}\text { v. Synthesizing } \\
\text { evidence }\end{array}$ & 1.7 & 3.4 & 9.2 & 28.6 & 57.1 & $4.4(0.9)$ \\
\hline $\begin{array}{l}\text { vi. Implementing } \\
\text { recommendations to } \\
\text { practice }\end{array}$ & 0.9 & 0.9 & 8.6 & 27.6 & 62.1 & $4.5(0.8)$ \\
\hline $\begin{array}{l}\text { vii. Understanding re- } \\
\text { search and statistical } \\
\text { terms and methods }\end{array}$ & 2.5 & 2.5 & 5.0 & 24.4 & 65.6 & $4.5(0.9)$ \\
\hline Overall Mean (sd) & & & & & & $4.5(0.5)$ \\
\hline $\begin{array}{l}\text { xi. Other training ar- } \\
\text { eas ( } n=9 \text { comments } \\
\text { summarized to the } \\
\text { right): }\end{array}$ & $\begin{array}{l}\text { (0.5 } \\
\text { EBP } \\
\text { cour } \\
\text { to sc } \\
\text { rese } \\
\text { disc } \\
\text { sem }\end{array}$ & $\begin{array}{l}\text { s to } \\
\text { je ba } \\
\text { ch tr } \\
\text { sions } \\
\text { ars a }\end{array}$ & $\begin{array}{l}\text { I time } \\
\text { olaces; } \\
\text { scuss } E \\
\text { ers to } \\
\text { ing; in } \\
\text { egardir } \\
\text { I staff c }\end{array}$ & $\begin{array}{l}\text { BP on } \\
\text { BP; ba } \\
\text { erenti } \\
\text { g emer } \\
\text { evelop }\end{array}$ & $\begin{array}{l}\text { ious to } \\
\text { c and a } \\
\text { statist } \\
\text { ng nur } \\
\text { ent wo }\end{array}$ & $\begin{array}{l}\text { uation of } \\
\text { II MSN } \\
\text { ics; how } \\
\text { vanced } \\
\text { s; panel } \\
\text { ng issues; } \\
\text { kshops }\end{array}$ \\
\hline
\end{tabular}

\section{DISCUSSION}

The majority (93\%) of respondents in this study reported that they had no previous training in EBP. Majid et al. reported that $82.7 \%$ of nurses surveyed in Singapore had not had previous EBP training. ${ }^{7}$ These findings suggest that nursing schools in Nepal consider integrating EBP into their curricula, and that health care organizations provide EBP as continuing staff development. The majority of the study respondents demonstrated positive attitudes toward EBP, consistent with findings from previous research. ${ }^{8,10-12}$ However, the findings suggest that there are a number of barriers that limit the implementation of EBP in Nepal. The greatest barrier identified was the lack of adequate time and workload release, similar to findings reported from previous studies. ${ }^{7,9,10,12-16}$ Another barrier identified by $52.9 \%$ of the respondents was the lack of sufficient resources, which was also identified by Majid in Singapur and by Chemjong in her study of Nepalese nurses. ${ }^{7,9}$

Respondents ranked all seven potential motivators that were listed on the survey as important for promoting EBP. Five of these were also identified by respondents in the survey conducted by Majid (training, protected time, supportive management, mentoring, and access to a system for comprehensive literature searching). The respondents' qualitative comments to the question about strategies that could promote EBP were consistent with their ratings of specific motivating factors that were listed in the survey,
Table 9. Information Resources Used

\begin{tabular}{|c|c|c|c|c|c|c|}
\hline \multirow[t]{2}{*}{ Print Information Sources } & \multicolumn{3}{|c|}{ Never } & \multicolumn{2}{|c|}{ Always (\%) } & \multirow{2}{*}{$\begin{array}{l}\text { Mean } \\
\text { (SD) }\end{array}$} \\
\hline & 1 & 2 & 3 & 4 & 5 & \\
\hline i. Textbooks & 2.1 & 1.1 & 17.0 & 24.5 & 55.3 & $4.3(0.9)$ \\
\hline ii. Journal articles & 2.5 & 15.1 & 37.0 & 22.7 & 22.7 & $3.5(1.1)$ \\
\hline iii. Newspapers & 7.8 & 18.1 & 37.1 & 31.9 & 5.2 & $3.1(1.0)$ \\
\hline $\begin{array}{l}\text { iv. Pamphlets/handouts } \\
\text { (produced by healthcare com- } \\
\text { panies, hospitals) }\end{array}$ & 4.3 & 17.9 & 36.8 & 25.6 & 15.4 & $3.3(1.1)$ \\
\hline v. Reference books & 6.0 & 7.7 & 24.8 & 40.2 & 21.4 & $3.6(1.1)$ \\
\hline vi. Other print sources $(n=5)$ & \multicolumn{6}{|c|}{$\begin{array}{l}\text { Internet also for nursing management; Litera- } \\
\text { ture; Hospital protocols; Published journals }\end{array}$} \\
\hline vii. Nursing e-books & 9.6 & 11.7 & 33.0 & 29.8 & 16.0 & $3.3(1.2)$ \\
\hline $\begin{array}{l}\text { viii. Digital medical and nurs- } \\
\text { ing libraries }\end{array}$ & 15.2 & 15.2 & 31.3 & 28.6 & 9.8 & $3.0(1.2)$ \\
\hline $\begin{array}{l}\text { ix. Health databases (e.g. } \\
\text { CINAHL, PubMed) }\end{array}$ & 2.5 & 17.8 & 33.9 & 32.2 & 13.6 & $3.4(1.0)$ \\
\hline $\begin{array}{l}\text { x. Human information } \\
\text { systems }\end{array}$ & 9.8 & 11.6 & 29.5 & 31.3 & 179 & $3.4(1.2)$ \\
\hline $\begin{array}{l}\text { xi. Google (websites providing } \\
\text { information about a specific } \\
\text { problem) }\end{array}$ & 1.7 & 7.8 & 10.4 & 16.5 & 63.5 & $4.3(1.1)$ \\
\hline \multicolumn{2}{|c|}{ xii. Other electronic resources $(n=4)$} & \multicolumn{5}{|c|}{$\begin{array}{l}\text { Hinari (2), eNomed, Scribd, } \\
\text { Google Scholar }\end{array}$} \\
\hline xiii. Work colleagues & 3.5 & 4.7 & 29.4 & 36.5 & 25.9 & $3.8(1.0)$ \\
\hline xiv. Nursing supervisor & - & 6.3 & 26.8 & 31.3 & 35.7 & $3.9(0.9)$ \\
\hline xv. Nursing management staff & 3.5 & 9.7 & 30.1 & 31.0 & 25.7 & $3.7(1.1)$ \\
\hline $\begin{array}{l}\text { xvi. Nursing research commit- } \\
\text { tee or EBP group }\end{array}$ & 18.6 & 15.9 & 26.5 & 22.1 & 16.8 & $3.0(1.3)$ \\
\hline xvii. Doctors & 9.6 & 12.3 & 34.2 & 27.2 & 16.7 & $3.3(1.2)$ \\
\hline Overall Mean (sd) & & & & & & $3.5(0.6)$ \\
\hline xviii. Other $(n=2)$ & Self- $k$ & owled & , lectu & & & \\
\hline
\end{tabular}

although additional motivators were identified from the qualitative comments including journal clubs or EBP rounds, opportunities to conduct research, and policies related to EBP. These findings provide further guidance for developing strategies to promote EBP in Nepal.

The top two ratings to the questions about specific training needs identified by the respondents in this survey were the same as the top scores identified by respondents in the survey by Majid "identifying clinical issues for implementing EBP," and "identifying what EBP is." The mean scores for the seven specific training needs reported by respondents in the Singapore study ranged from 3.74-3.92, whereas the scores for respondents in this study were higher (ranging from 4.3-4.6). Similar to the findings reported by Majid et al. respondents in this study reported low use of electronic information resources. ${ }^{7}$ These findings can be used to develop priorities for EBP training programs for nurses in Nepal.

There were several limitations of this study that must be acknowledged. The first is that the survey was conducted only in English and the sample was small. Although the EBP conference was conducted in English and all of the participants were able to speak and write in English, some of the items on the survey may have been difficult for 
participants to understand. The findings may also have been skewed because the participants were attending an EBP conference, so their responses may not reflect the knowledge, attitudes, and perceptions of nurses throughout Nepal. Although the instrument used had content validity and acceptable internal consistency reliability and had been used previously in Singapore, it had not been validated in Nepal. The Cronbach Alpha reliabilities for the scales in this study ranged from 0.63 to 0.86 . Two scales had reliabilities less than 0.70 (the 5 -item scale measuring attitudes towards EBP and the six item scale measuring Perceived Motivators for EBP). Majid et al. reported Cronbach reliabilities of 0.68 and 0.91 , respectively, for these two scales. ${ }^{7}$ Further research is needed to assess the reliability and validity of these scales with Nepalese samples. Similarly, the instrument measured participants' self-assessments of their knowledge and skills in EBP, and these assessments may not have been accurate reflections of their actual knowledge or skills.

Strength of this study is that it is one of the first efforts to assess EBP knowledge, skills and attitudes among nurses or nursing students in Nepal. No other published studies on this topic were identified in the literature, although there was one other presentation at the EBP conference on this topic. ${ }^{9}$

There are many implications of the study findings for nursing education. There is a clear need for additional education about EBP in Nepal both within schools of nursing and within practice settings. The specific training needs that were identified could be used to guide such programs. Schools of nursing might consider changing the focus from teaching traditional research methods to teaching students how to appraise and apply evidence to their practice. Many nursing programs in Nepal do not introduce research courses until the final year of the program. Introducing EBP early in the program could help students to develop skills that could translate into their practice after graduation.

The study findings also have many implications for nursing practice. Motivating factors that were identified could be used to implement practice changes to promote EBP (particularly providing more time for EBP, reducing the nurse-patient ratio, providing mentors, supportive environments, ensuring availability of resources for literature review, and offering journal clubs or EBP rounds). Developing collaborations between nursing education and practice sites could help to address the need for mentoring and support that was identified by many of the respondents as potential motivators for EBP. Ensuring that policies and procedures are evidence-based could also reinforce the implementation of EBP in practice settings. Librarians can be invaluable resources in practice environments to facilitate identification of relevant information that can be used by health professionals to address clinical practice issues.

There is clearly a need for additional research with diverse samples of nursing students and practicing nurses in all regions of Nepal. The instrument used in this study could be used by EBP committees in hospitals and other clinical practice sites to provide baseline information and guide development of strategies to address specific needs at each site. There is also a need for additional research using different instruments to measure actual EBP knowledge and skills as well as the extent to which nurses implement EBP in their practice settings.

\section{CONCLUSION}

Because nurses play a crucial role in the delivery of health care, they need to embrace new and innovative techniques to provide effective and best possible treatment to their patients. The findings from this study suggest that although this sample of Nepalese nurses and students had positive attitudes towards EBP, their knowledge and skills were limited, and there are many barriers to implementing EBP in Nepal. Nursing faculty can use the findings to guide implementation of EBP into curricula, and nursing administrators and clinicians can use the findings to guide practice changes to promote EBP. The first international EBP conference held in Nepal in November 2014 provides an excellent beginning to expand EBP and contribute to improved nursing practice and health outcomes in Nepal.

\section{ACKNOWLEDGEMENT}

The authors acknowledge the support of the University of Alabama at Birmingham Sparkman Center for Global Health, Kathmandu University of Nepal, and thank all participants for their valuable help and enthusiasm in conducting this study.

\section{REFERENCES}

1. Behague D, Tawiah C, Rosato M, Some T, Morrison J. Evidence-based policy-making: the implications of globally-applicable research for context-specific problem-solving in developing countries. Social Science \& Medicine. 2009;69(10):1539-46.

2. McClellan MB, McGinnis M, Nabel EG, Olsen LM. The National Academies Collection: Reports funded by National Institutes of Health. Evidence-Based Medicine and the Changing Nature of Healthcare: 2007 IOM Annual Meeting Summary. Washington (DC): National Academies Press (US). National Academy of Sciences; 2008.

3. Pappaioanou M, Malison M, Wilkins K, Otto B, Goodman RA, Churchill $\mathrm{RE}$, et al. Strengthening capacity in developing countries for evidencebased public health: the data for decision-making project. Soc Sci Med. 2003;57(10):1925-37.

4. World Health Organization. Guidelines for WHO Guidelines. Geneva, Switzerland: 2003.

5. Melnyk B, Fineout-Overholt E. Evidence-based practice in nursing \& healthcare: A guide to best practice. Philadelphia: Wolters Kluwer/ Lippincott Williams \& Wilkins; 2011. 
6. Pravikoff DS, Tanner AB, Pierce ST. Readiness of U.S. nurses for evidence-based practice: many don't understand or value research and have had little or no training to help them find evidence on which to base their practice. American Journal of Nursing. 2005;105(9): 40-52.

7. Majid S, Foo S, Luyt B, Zhang X, Theng YL, Chang YK, et al. Adopting evidence-based practice in clinical decision making: Nurses' perceptions, knowledge, and barriers. Journal of the Medical Library Association. 2011;99(3):229-36.

8. Heydari A, Mazlom SR, Ranjbar H, Scurlock-Evans L. A Study of Iranian Nurses' and Midwives' Knowledge, Attitudes, and Implementation of Evidence-Based Practice: The Time for Change Has Arrived. Worldviews on evidence-based nursing/Sigma Theta Tau International, Honor Society of Nursing. 2014.

9. Chemjong $P$, editors. Perceived facilitators and barriers towards evidence based nursing practice. First International Nursing Conference - Enhancing Evidence Based Nursing Practice; 2014; Dhulikhel, Kavre, Nepal.

10. Sticler J, Fache F, Fields W, Fhimss S, Brone C. Faculty Knowledge, Attitude and Perceived Barriers to Teaching Evidence-Based Nursing. Journal of Professional Nursing. 2011;27(2):92-100.
11. Upton D, Upton P. Development of an evidence-based practice questionnaire for nurses. Journal of Advanced Nurses. 2006;53(4).

12. O'Connor S, Pettigrew CM. The barriers perceived to prevent the successful implementation of evidence-based practice by speech and language therapists. International Journal of Language Communication Disorders. 2009;44(6):1018-35.

13. Ammouri AA, Raddaha AA, Dsouza P, Geethakrishnan R, Noronha JA, Obeidat AA, et al. Evidence-Based Practice: Knowledge, attitudes, practice and perceived barriers among nurses in Oman. Sultan Qaboos University Medical Journal. 2014;14(4):e537-45.

14. Griffiths JM, Closs SJ, Bryer RM, Hostik T, Kelly S, Cooke J. Barriers to research implementation by community nurses. British Journal of Community Nursing. 2001;6(10):501-10.

15. Mclnerney P, Suleman F. Exploring knowledge, attitudes, and barriers toward the use of evidence-based practice amongst academic health care practitioners in their teaching in a South African university: a pilot study. World views of Evidence Based Nursing. 2010;7(2):90-7.

16. Solomons NM, Spross JA. vidence-based practice barriers and facilitators from a continuous quality improvement perspective: an integrative review. Journal of Nursing Management. 2010;19(1): 109-20. 